\title{
NMES
}

New Middle Eastern Studies

ISSN: 2051-0861

Publication details, including guidelines for submissions:

https://journals.le.ac.uk/ojs1/index.php/nmes

\section{Hip-Hop in the Arab World and Kuwait}

Author(s): Shahd Alshammari and Rami Chahin

To cite this article: Alshammari, Shahd and Rami Chahin (2021) "Hip-Hop in the Arab World and Kuwait", New Middle Eastern Studies 11 (2), pp. 74-86.

Online Publication Date: 2 March 2022

\section{Disclaimer and Copyright}

The NMES editors make every effort to ensure the accuracy of all the information contained in the journal. However, the Editors and the University of Leicester make no representations or warranties whatsoever as to the accuracy, completeness or suitability for any purpose of the content and disclaim all such representations and warranties whether express or implied to the maximum extent permitted by law. Any views expressed in this publication are the views of the authors and not the views of the Editors or the University of Leicester.

Copyright New Middle Eastern Studies, 2022. All rights reserved. No part of this publication may be reproduced, stored, transmitted or disseminated, in any form, or by any means, without prior written permission from New Middle Eastern Studies, to whom all requests to reproduce copyright material should be directed, in writing.

\section{Terms and Conditions}

This article may be used for research, teaching and private study purposes. Any substantial or systematic reproduction, re-distribution, re-selling, loan or sub-licensing, systematic supply or distribution in any form to anyone is expressly forbidden.

The publisher does not give any warranty express or implied or make any representation that the contents will be complete or accurate or up to date. The accuracy of any instructions, formulae and drug doses should be independently verified with primary sources. The publisher shall not be liable for any loss, actions, claims, proceedings, demand or costs or damages whatsoever or howsoever caused arising directly or indirectly in connection with or arising out of the use of this material. 


\title{
Hip-Hop in the Arab World and Kuwait
}

\author{
Shahd Alshammari ${ }^{*}$ and Rami Chahin ${ }^{* *}$
}

\begin{abstract}
It is no wonder that young generations in the globe as well as in the Arab World are attracted to hip hop music that absorbs a load of incompatible emotions in a world of many conflicts and contradictions. The American roots of hip hop culture attract the young generation in the Arab World. This article examines examples from Arab and Gulf hip hop culture. A successful and distinguished Kuwaiti hip hop duo, Sons of Yusuf, has been interviewed to highlight their experience using bilingualism and reflecting on their traditions and culture. The group has worked hard to showcase the new factors that they have introduced to the knowledge of music in Kuwait and to the music life in the Arab World in general. Considering their lyrics and choices, Sons of Yusuf aim to express a Khaleeji identity that embraces history, tradition, and collective memory.
\end{abstract}

Keywords: Arab World; Gulf; Hip Hop; Kuwait; Identity

\section{Introduction: Arab Rappers in and out of the Arab World}

Hip hop is the dominant music and culture of most of the inner cities in the USA. Since its emergence in the 1970s, hip hop has soared around the world due to many reasons. One reason relates to the ease of producing this type of music as only one musician or two are able to produce it. Another reason is that hip hop music provides a margin of freedom for people, especially for the young generation, to express their opinions and feelings towards different issues. Hip hop musicians do not need to play or to practice musical instruments regularly. In addition, they do not need previous knowledge and hip hop music is not expensive to produce.

Another factor that has enhanced the spread of hip hop music is the fact that the US inner-cities are centers for lower-income minorities who live side by side with the majority of African and Latin American people, many of whom are fans of hip hop, and have prompted rapid spread of it around the world (Sciullo 2019). Most of the minorities in the USA are bilingual and multicultural. Each group has a message to pass through variant music, which positions them as cultural ambassadors for their communities in the USA and in their original

\footnotetext{
"Shahd Alshammari, Assistant Professor of English, Gulf University for Science and Technology, Kuwait. Email: alshammari.s@gust.edu.kw.

${ }^{* *}$ Rami Chahin, Assistant Professor of Musicology, Oldenburg University, Germany. Email: ramichahin7@gmail.com.
} 
countries. The young Arab community is one of these groups which find in hip hop the means to express their viewpoints not only within their new American communities but also in their homeland and across the world (Cainkar and Louise 2013). Clear examples of hip hop music can be located around the world: French Montana Moroccan-American, DJ Khaled and Fredwreck Palestinian-American, Salah Edin a Dutch-Moroccan, Rilès a FrenchAlgerian. Although there are similarities in many topics (e.g. love, wealth, poverty, relationship, peace, drugs and other social issues) between Arab rappers in the Arab World and in the land of immigration, there are still many essential issues which cannot be discussed, especially in regards to politics. Nevertheless, hip hop diversities are varied across the cultures of the Arab World.

Hip hop functions differently in each society, localizing and lending itself to cultural and artistic expression. Hip hop is "appropriated and transformed by local artists in different parts of the world... many have found hip hop gives them the space as well as the freedom to participate in the public discourse of their society" (Kahf 2007). As such, hip hop in the Arab World and the Gulf offers a voice for artists to participate in the grand narrative of the Arab World, challenging homogenizing narratives, and allow for various ruptures in the narrative. The artists create diverse narratives that speak for and to each society's history and sociopolitical issues. Some scholarly work has been produced on the importance of hip hop and artistic expression and resistance. For instance, communications scholar Haneen Alghabra (2020: 187) argues that Palestinian hip hop functions as a site of resistance through communicating important issues about the nation:

Thus, Palestinian hip-hop has become a vehicle for sharing social and political oppression as well as a means for mobilization... For instance, the way in which music, lyrics, and images come together allow us to understand how music videos reflect public discourse... In turn, music creates debate around issues of war, identity, gender, citizenship, and international relations, and is filled with anxieties about identity, colonialism, Zionism, and apartheid. Hence, rappers are continuing performance poetry of earlier genres that expressed their political critiques through the performative, such as Edward Said, Mohammed Darwish, and Naji Al-Ali.

As such, Palestinian hip hop is able to move across borders and boundaries, thereby challenging political sanctions and oppression. In this sense, Palestinian hip hop is an excellent example of how hip hop can be mobilized as a site of creative resistance to the grand meta-narrative. Through performance, rappers are able to write their voices into public discourse, affecting generations of people, and expressing their concerns about their lived realities. As such, hip hop is both personal and political. Even more pressing is the question of Arab hip hop as multidimensional. In their excellent contribution to the music of the Arab World, editors Thomas Burkhalter and Kay Dikinson contend that "when one types 'Arab + music' into an academic search engine, it is rare not to find the results also clumped under the heading 'traditional', so closely do the terms cohabit, at least in English- language debate" (2013: 9). Unlike reductive search engines and simple generalizations, a survey of various hip hop in parts of the Arab World is necessary to localize the genre. 


\section{Varieties of Hip Hop in the Arab World}

The Arab World has been a hot spot for a variety of actions and contradictions. There are wars, revolutions, conflicts, political corruption - in addition to a variety of religious sectarian struggles and other socio-political problems. Besides all these dilemmas that rappers have to contend with, there is the ordeal of confronting the Arab politicians, governments and religious authorities during the last decades. What makes Arab rappers attracted to hip hop is that it is easy to learn and it is easy to create.

Arab rappers find in hip hop the other face of classical Arab music which is almost similar in theory and in instrumentation in almost all the Arab countries and which requires at least a good lyric writer, a good composer, a good singer, good musicians and studio. On the other hand, hip hop music does not require much which is exactly why it can have various shapes. Hip hop can be divided in the Arab countries into three main styles. The first one is just imitating North American and European hip hop style with no big change except the language which is most likely a colloquial local Arabic language. Some rappers sing also in other languages like English, mainly in the Gulf, and French, mainly in North-West Africa (Maghreb). This style of hip hop is most common in Arab countries because it is performed in colloquial local language and the entire work can be done by just one rapper. Sometimes the rappers in this style use very simple Arab sound techniques. Each Arab country has gradually generated its own established rappers. For example, some of the popular works include the Tunisian Balti' Bouheli, the Syrian Bu Kolthoum's Zamilou, Volcano Mc Wajbe Dbl, from Saudi Arabia Klash Daes, Asayel Slay Bnt Mecca, Ahmedoo biggie hoopay, and from Kuwait Killa D My Way in addition to Frizzy's Kuwait City Be Like.

The second style is somewhat similar to North American and European hip hop but it is also mixed with traditional local Arab music rhythms, Arab instruments and melodies (which can be classical Arab music, local traditional music or/and pop Arab celebrating electronic music). Some examples include the music of the Egyptian actor/rapper Ahmed and Mahmoud Al Liethy's Akhret Al Shaqawa, the Bahrain Daffy \& Flipperachi's Shoofha, the Syrian Sayed Darwish and El Rass's Ya deeb, the Algerian Nima Psy's Hip Hop Zenda and from Kuwait, Sons of Yusuf's A Night in Córdoba. Although this style of hip hop is closer to the Arab societies, it is less used as it is, for many rappers, more complicated than the previous one. In addition to the previous examples, a creative style can be added to the previous ones, where no techno and computer music are more widely used. It inspired its music from Jamaican reggae ska and rocksteady and also from the Arab music. It is sometimes accompanied by some simple Arab rhythms and melodies. Sharmoofers's Single from Egypt is a good example of this style.

The third style can be described as free local hip hop music. In each country we find hip hop, like for example the mahraganat (Celebrations) electro-chaabi (Peavey 2014), which exists only in Egypt. It is not clear if it has real influence from other styles of hip hop, because it started and soared up fast in poor El Salam City/Cairo 2006-2007 to replace the pop traditional music especially in wedding ceremonies. This popularity was due to many reasons. Again, it is easy and cheap to produce by using sound libraries and effects, in addition to the dominance of the celebrated pop traditional shaabi singers (Nāğy 2016). It is a unique style of hip hop that has less reggae influence but more similarity to reggaetón. The 
similarity between the rap singing, on one hand, and the Arab singing technique mawwal and the tahiyat $^{1}$ on the other hand simplifies the work of the Arab rapper to develop this inbetween new style of hip hop.

Normally, mahraganat music is based on intensive continuance rhythmical claps and a cymbal or castanets playing in the beat value without any change. Besides, several Arab percussion instruments play the rhythm; however, they are used simultaneously with beat value. The instrumental sounds can be only electronic sound samples. Usually, traditional celebrating musical instruments and vocal effects like Auto-Tune with simple Arab melodies and rhythms can be added. The rhythm is almost the same rhythm 4/4 maqsoum (Kharsa 2015). The switch between the rap tracks and the traditional celebrating parts causes stimulatory effects. Therefore, this style of hip hop gained popularity from wedding celebrations, where it was started, to taxis tutuks, and to streets and to films. Actors like Mohamed Ramadan and Mohamed Saad sing also in this style of hip hop. Some other important names and bands in mahraganat are: El Madfaagya, Oka \& Ortega, Elseweasy, 8\%, Sadat, Amr Kamal, Hamo Beka, Hassan Shakoush, Amr Haha, Isam Sasa and Islam Chipsy. Sometimes there are cooperative works between the mahraganat artists from Egypt and hip hop artists from the Arab Gulf like: Flipperachi (Bahrain), Daffy (Kuwait) \& Sadat 3ali 3al Mazeeka.

\section{A Concise Overview of Hip Hop in the Arab Gulf and Kuwait as a Case Study}

For the same reasons that cause hip hop to thrive in Egypt, hip hop finds its way to other Arab countries through the traditional music in each country. Most types of the traditional songs in the Arab Gulf follow rhyme, narrative and descriptive language like: al-sheileh (sea songs), al-sinkini, al-nahham/nahmeh and al-mawwal in Kuwait (Nahmah 2017). The nahmeh is similar to al-hedadi in Bahrain, where the tempo of al-hedadi is faster than alnahmeh. (Kaoubi 2017) Due to the seamen's life, which it was the main job of the people in the Khalij, music instruments were mainly percussion instruments, like: Mirwas, Manjur, yahla/jahla, tablah, (Killius 2017) claps, and in the cities of Gulf countries we find other Arab traditional classical instruments such as oud, nay, mejuez and rababeh. The variety of singing techniques accompanied by percussion instruments and the lop melodies make the Gulf music comparable to hip hop and easy to be mixed like the music of the Saudi rapper Slow Moe Yalolo. Sometimes the auto-tune is used with fast rhythms as in al-sheileh, which can be heard as a hip hop which can be also compared to the mahraganat in Egypt (Zfat afrah aleursuih 2020). This similarity eases the mission of the young Gulf rappers to work with hip hop music. Popular culture and music in the Arab Gulf states raises questions about identity, language, and politics, and it is worth noting that the popular culture in the Gulf has many artistic expressions (Alsharekh 2012).

Almost all Gulf rappers are classified in the first and the second styles of hip hop (mentioned above) where their hip hop music is either identically similar to the western one or with influence of Gulf traditional music, like the music of DJ-MK, Slow Moe, Flipperachi. What is especially interesting in Kuwait is the collaborative work of a group of rappers, who shot two videos to support hip hop music in Kuwait and to keep it alive. The videos which 
can be found on YouTube go back to 23 Jul 2012. The participants are the following: Big D, Emcee Element, D-ZL, John Skywalker, Deep Raw, Duffy, Traphique, Solo, LC, Chaotic LP, Shane, Mejudice, Killa D, Djiby, Armani, Scarbenface Delavega and Bugzy (Big D Kuwaiti Rapper 2012). The musicians discuss many topics in these two short videos, even touching upon politics to criticize the USA policy in the Middle East.

One interesting case study in the Middle East is Kuwait and its creative sector, affected by the discovery of oil, the Gulf War, and later the aftermath of the war and its social consequences. Kuwait was known as the "Pearl of the Gulf" and was the largest producer of oil from 1953 to 1966, which created a cultural and creative boom during the 1970s to the 1980s (Urkevich 2018: 21). Kuwait was leading the field of music and arts and then struggled after the Gulf War to return to a pre-war state of creative production. Urkevich (2018: 21) outlines the changes between post-oil Kuwait and post-war:

Radio stations, recording studios, television, and musical performances blossomed, and the eyes of all neighbouring Peninsula countries eagerly turned to Kuwait for creative leadership. Subsequently, the 1990 Gulf War and its aftermath brought a cultural shift and a massive decline in artistic support.

Although Kuwait struggled after the Gulf War, many artists continued to produce music and dedicated themselves to re-establishing Kuwait's arts and culture scene. Over the past few decades, the Kuwaiti government has placed emphasis on reviving pre-Gulf War arts and music. Urkevich's (2018: 21) analysis confirms this:

On 31 October 2016 the lavish Jaber Al-Ahmad Cultural Centre (JACC), comprising several state-of-the-art theatres, rehearsal spaces, music facilities, conference halls, and a cinema, was inaugurated with a goal to return Kuwait to the regional helm of artistic culture...Kuwaiti music has always been dynamic and improvisatory, and making its character accessible to modern audiences is in line with the fluidity and creativity intrinsic in Kuwaiti arts.

The duo named "Sons of Yusuf" follow the above line of thought and have a similar vision of reviving Kuwait's music scene, improvising different techniques and blending types of music to reflect both Kuwait's past and present. Sveltana Boym writes about historical nostalgia in the context of nationalism and identifies two types that are motivators for the present: restorative nostalgia and reflective nostalgia (2001). Restorative nostalgia can help with rebuilding and achieving a new-founded sense of personal and collective identity. Boym states, 'The fantasies of the past, determined by the needs of the present, have a direct impact on the realities of the future' (2007: 8). In this sense, Sons of Yusuf use restorative nostalgia as a critical building tool throughout their music. They write about pearl diving, the Gulf War, and what this has taught to Kuwait's people. By highlighting the past, they blend the present in a reflective nostalgic way, taking pleasure in the past, while still looking forward. Many scholars have suggested the importance of considering critical nostalgia as a positive tool for embracing national identity and history (Alragam 2015; Ray 2006). In this context, some of the lyrics for the song entitled "Diving for Pearls" include: 


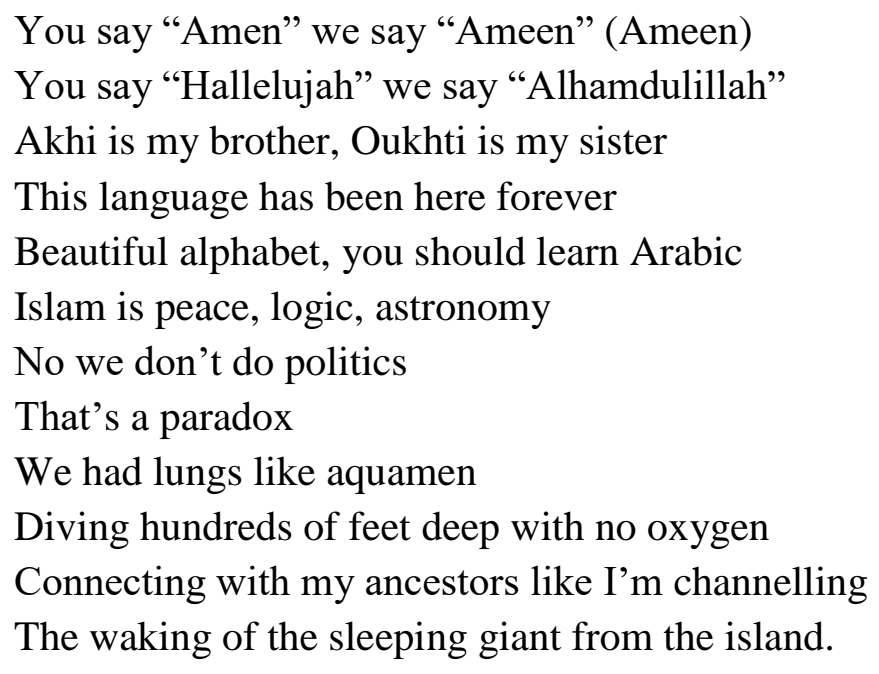

The above lyrics connect the past to the present, reflecting on language differences between the so-called East and West, introducing the beauty of the Arabic language, Islam and peace, and stating that they "don't do politics" which in itself is a form of resisting the dominant Orientalist/Eurocentric stereotype of the Arab World as fuelled with political rage and revolution. Contextualizing their work in this song is necessary to understand how their music makes use of restorative nostalgia to assert Kuwaiti history and its connections to the present, despite globalization and the English language's infusion with their music. Their mission is to reflect on Kuwait's cultural heritage, history, and take pride in both the past and present-day Kuwait. To know more about their music and mission, an interview was arranged with Yacoub Alrefaei, the elder brother and the founder of the duo Sons of Yusuf.

\section{Sons of Yusuf: Between Language, History, and Identity}

Sons of Yusuf began by making viral Arab-flavoured remixes of hip-hop hits, but have blossomed into an international phenomenon. Their 2018 single "One Time" went \#1 in Kuwait and achieved radio play in France, Morocco, UAE and the rest of the Gulf region (Saeed 2018). As such, our choice to interview them was based on their ability to mix Kuwaiti culture with American hip hop as well as their regionally influential presence. The duo stands out from the rest of the artists in Kuwait because of their unique blending of languages and cultures as well as their choice of content. Most significantly is their reflective tone in their lyrics, nostalgic for an older Kuwait. The music itself carries an appreciation for Kuwait's maritime culture, history, and memories. Chanting was a huge part of "Kuwait sea songs" - the songs that accompanied pearl drivers on ships during their expeditions. Kuwaiti sea songs, like most Arabic folk songs, depends primarily upon the vocal quality of the singer; musical instruments only have a secondary role in the overall configuration of Kuwaiti maritime songs, enhancing the human voice and providing the song with harmonic support" (Al-Rifai 1987).

Sons of Yusuf make use of chanting throughout their music, citing Kuwaiti sea songs as inspiration and a culture that ought to be preserved. Their music is nostalgic towards sea- 
songs and maritime culture. Historically, pearl diving boats included a lead singer who would entertain and support the sailors throughout their journey:

One of the most important members of the crew found on most pearl diving boats was a lead singer known as a nahha ${ }^{-} \mathrm{m}$ (plural nahha-ma or naha-' $a m 1^{-} \mathrm{n}$ ), that is, one who "wails or laments," as he represents the pain and longing of the pearlers. "Nahha"m" in Arabic indicates a roar, a sound of an elephant or lion, and also means to reach the ultimate degree of ardor, to have a burning desire. The nahha $\mathrm{m}$ singer is loud and of strong voice but also performs with great passion. Sometimes, because the singing was so strenuous, there was a second nahha $\mathrm{m}$ to relieve the first (Urkevich 2015: 156).

In the same vein, Sons of Yusuf as a duo speak to each other and assist each other in their chanting, rapping, and performance. As a duo, they believe that their work benefits from each other's presence throughout the songs. The name of the band, "Sons of Yusuf", was inspired from the first supporter for the brothers, their father Yusuf Alrefaei, who has been giving them the support and motivation for their music. As a duo, they are grateful to their father, hence emphasizing Kuwait's collective culture and the value placed on identity as tied to the family, as evidenced in the choice of the band's name. In our interview, Yacoub explains it as follows:

He's always been pushing us to do something, not just musically, but he was always inspiring us to do something to change the world, to go out, help people, to do something. Especially with music.

Attending primary school in California gave the brothers the opportunity to meet Western popular culture and music, especially hip hop and rap. They participated in many events using music of North American hip hop artists. The first change in their life happened when their friends and teachers started to ask them to present something from their Arab culture, including traditions and religion, which awoke their curiosity to know more about their cultural origin. Brothers Alrefaei found in hip hop a means to represent their culture:

Honestly, my dad used to try to get us into piano lessons or guitar lessons, but we never really held onto it. We kept jumping from one instrument to another. Obviously, with hip-hop, you don't need to go to school for hip-hop...We heard different people rap on the streets of California, and we were called upon to do the same, to chant back, to rhyme back, and to talk about our culture. We wanted to set the record straight, that Arab culture is isn't just about terrorism, that there's a long history that is forgotten.

The emphasis on a history that is "forgotten" re-asserts the need for restorative nostalgia. The brothers began considering ways that hip hop could be a means to express their culture, history, and to cross national frontiers. They started "Arab" hip hop by mixing Arab music such as Fayrouz (Lebanese singer) and Umm Kulthum (Egyptian singer), and turning it into hip hop. Such intercultural ideas opened for the two brothers a new hip hop perspective, by infusing the Arab Gulf traditional music in their music. Launching from this idea, they could develop their musical technique by replacing Fayrouz and Umm Kulthum with their own khaleeji "Arab Gulf”, Kuwaiti and Islamic music. They used some software such as Reason, 
Cool Edit, Pro Tools, Adobe Audition and Logic came after. The skill of using music software is also inherited from the father:

My dad and his friends were always building studios, so growing up, I used to always be around studios. I've seen a studio. I've seen a mixer, a mixing board. I've seen that since a young age.

Later, Sons of Yusuf got to know J Dilla, the famous hip hop producer, who enabled them to be professionals. For them, he was not just a producer and a friend but also an adviser and a master who inspired them. Since they moved back to Kuwait, Yacoub has been responsible for sound adjustment, video editing and for finalizing the production. Besides, the sound engineer, Mike Chav from Detroit, a good friend of theirs, who gives them hand and support. The band continues to grow and connect different cultures together.

One way that Sons of Yusuf are able to blend different cultures is through the usage of English and Arabic in the same song. By utilizing bilingualism, the duo is able to create music that infuses two languages, juxtaposing two or more cultures, and reflecting on the past and present. As in other Arab societies, the Kuwaitis live in the state of diglossia (Al Birini 2016), with the spoken dialect being considered the low variety and the standard dialect (Modern Standard Arabic) considered less popular. Sons of Yusuf use the Kuwaiti spoken dialect, with some phrases from standard Arabic as well as the English language. This bilingualism is part of the larger linguistic phenomena of code-switching. As scholar Holes (2011: 39) notes:

This kind of Arabic-English mixing, however, has now been overtaken by a new and seemingly more invasive phenomenon. What one now hears in the Gulf is codeswitching: the unpredictable to-ing and fro-ing between two languages, where a speaker might say three or four sentences in Arabic, then three or four in English. Sometimes a language switch will occur in the middle of a sentence.

The linguistic choice of blending Arabic and English in the same song reflects the new generation's ability to code-switch. Throughout our interview, as well as within the lyrics of Sons of Yusuf's songs, code-switching is prevalent. For example, one song has two titles, 'One Time' or in Arabic 'Ayam Al-Taybeen'. The song itself is nostalgic based on its title (ayam al taybeen translates as the days of the good old people) as well as its rhythmic chants, reminiscent of sea-songs, and its lyrics which start with "let's remember the good old days" (our translation). The rest of the song's lyrics find power in reminiscing about a time when things were simpler in Kuwait, when everyone in the same neighbourhood knew each other, and music was an integral part of Kuwaiti culture. The song's lyrics move back and forth between English and Arabic, and the song comes from the popular album entitled "Shaykh the World" (another play on words, shaykh meaning a ruler in the Gulf, and shake in English):

Haido haido, that's our camel lovely camel

I can go on and on. 


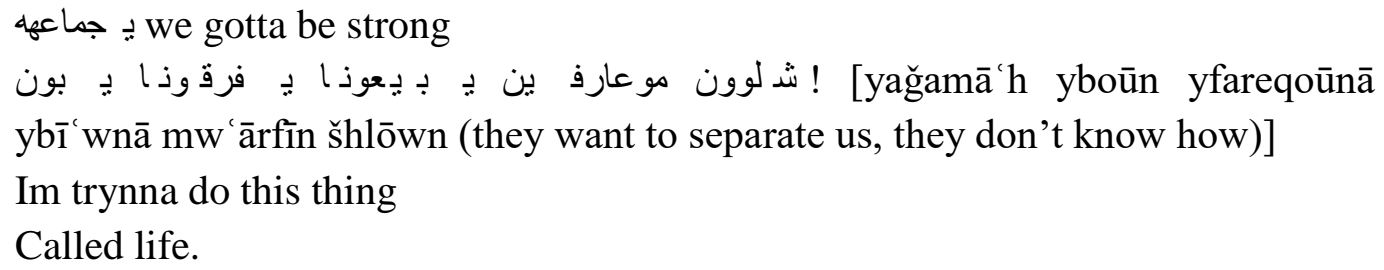

By calling upon the image of the camel, which in Orientalist terms is reductive, reducing the Arab World and the Gulf to images of the desert and camels, the brothers use the very same stereotype to claim it as our "lovely camel". Having lived in the West for a greater part of their lives, they are very much aware of the images and media representation used to homogenize the Arab World. Similarly to hip hop culture that reclaims identity through the choice of language that is otherwise derogatory, the brothers choose to use the same language, images, and prejudices towards Arabs and Muslims, by reclaiming this identity throughout their lyrics and music videos.

\section{Culture and Politics in the Music of Sons of Yusuf: Khaleeji “Arab Gulf” Music}

Often, the first impression of the viewers of the video clips of Sons of Yusuf is how much they are influenced and fascinated by the Khaleeji culture and society. It is obvious that they use in most of their musical recordings, in audio as well as in their video clips elements from the Khaleeji culture and society.

Before, in Kuwait every house had a musical instrument. We used to go to play music on the beach, on the street, you would see people playing music and drums, so that was, I think in my time at least, when I was younger in Kuwait, the youth, we all knew how to play the hand drum. Everyone had the rhythm and we played music together.

This metaphor from the Arab Khaleeji culture and society can be seen as an auto-stereostyle for exactly what Western sees as hitrostereostyle, where Arabs spend their money on imported luxury cars, accessories, buildings, visiting Western countries even though, they cannot leave their simple life, they ride camels, they wear Bedouin clothes, live in the desert and eat bread baked on ashes. Yacoub's opinion is that these stereotype samples bring more fun for our viewers, although they are an easy entertaining material to use. It is clear that the second reason behind this insistence on using these stereotype features is translated into autostereostyle which they like to use in every chance to show their Kuwaiti culture, which takes a major priority of their work in music and lyrics (Boylorn 2008; Calafell 2014). Very much aware that these stereotypes of Khaleeji and Kuwaiti culture are still dominant, the brothers produce the same images and exaggerate the lyrics as well as the scenes in the music videos. Choosing extravagant dress codes, cars, and camels, leaves them in a position that is popular with viewers. They speak English, code-switch, and yet are riding camels, and in the same music video switch to riding luxury cars. The music captures the multiplicity of Khaleeji and Kuwaiti identities, spaces, and images (Kraidy 2013). 
Although many of the topics they present have to do with politics, they try to keep a positive viewpoint that avoids confrontations and struggles. In their song entitled People of The Book ft. Isam B., we find that they are trying to defend Arab and Islam against the Western media which heavily demonizes both. The band insists that hip hop and lyrics can deconstruct and challenge the stereotype of Islamic terrorism. The song's lyrics highlight different religions "starting with Adam... Moses, Mohamed, Jesus, all had the same message, we are all one". The insistence on deconstructing and challenging Western (and Orientalist) images of Arabs and Muslims is part of the duo's mission. By using hip hop to rewrite the master narrative, Sons of Yusuf enter the conversation by challenging the way Gulf culture is globally perceived.

Another one of their songs situates Kuwait's collective trauma during the Gulf War. The song is entitled "Gulf War Syndrome" and expresses the personal and political traumas that took place. As they reflect on the war (reflective nostalgia), they also utilize restorative nostalgia, considering how the war has changed Kuwait's landscape and culture, leading to a more cosmopolitan Kuwait, one that includes more American influences, but also a country that still remembers (very vividly) the war. The lyrics are personal and political:

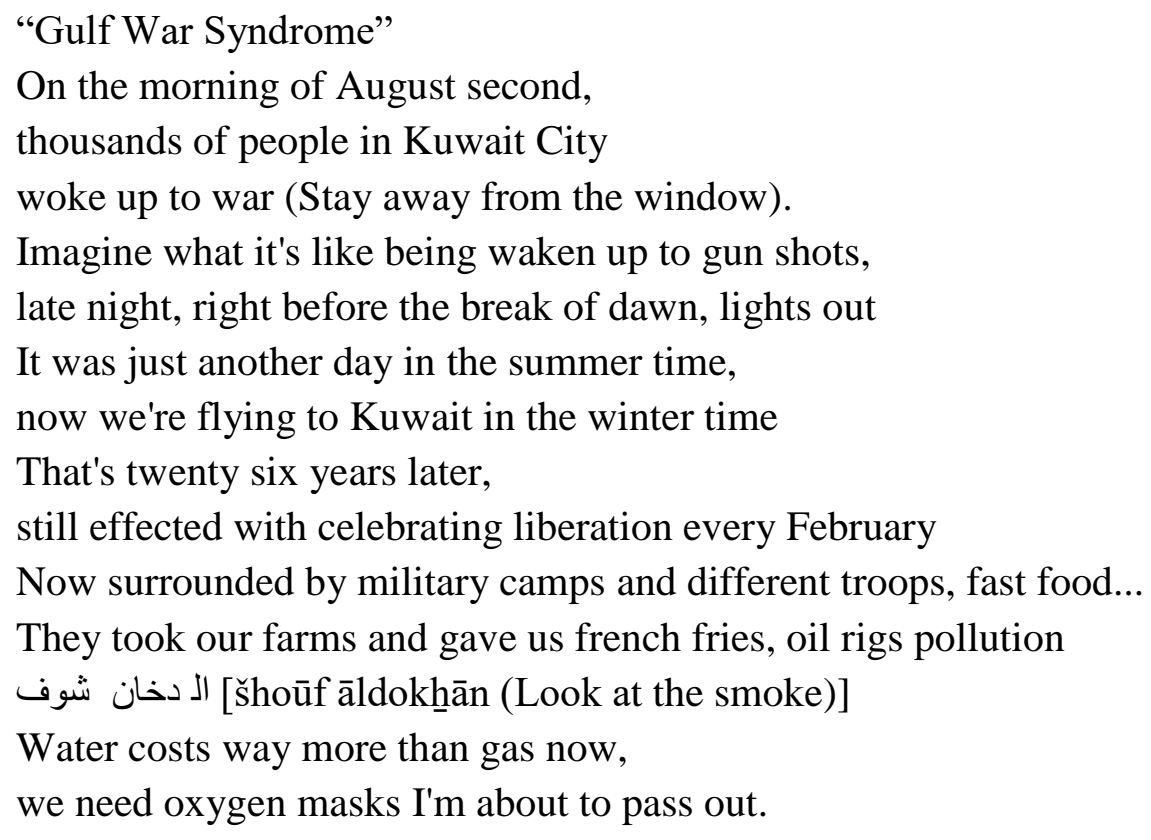

The lyrics are able to capture the essence of post-war Kuwait and the US presence in Kuwait. Other parts of the song include chanting in the Kuwaiti dialect and the beat of traditional drums. As such, the song is yet another example of the ways by which the duo have managed to use hip hop not just for entertainment but rather as a method for expressing personal and collective identities.

\section{Conclusion}

Hip hop has become the music of the new generations in many countries of the Arab World. The Gulf rappers have succeeded in their endeavour to attract their society to their style of 
music. In the Levant, it is the hip hop pro intifada and revolution and against war, corruptions and politicians. In the Maghreb, human rights and poverty are the main topics. From time to time, we find solidarity between rappers from the Arab countries and we find similar themes expressed in their music. Sons of Yusuf are a unique music group in Kuwait and the Gulf. Their success comes from representing the Khaleeji identity, culture, music, and society in their music and video clips.

Hip hop in the Arab World and more specifically in the Gulf region remains an underresearched topic and is far from being limiting, traditional, or monolithic. There are many questions that arise from considering hip hop Arab/Gulf culture, including its presence in society, its acceptance, its incorporation of various languages, and its representation of the past and present.

\section{Notes}

1. Tahiyat (ت ح يات). It is a welcoming speech or a message in a celebration that the singer or somebody else says it without sound melody accompanied by music with or without rhythm.

\section{References}

Albirini, Abdukafi (2016) Modern Arabic Sociolinguistics: Diglossia, Variation, Codeswitching, Attitudes and Identity ( London: Routledge).

Al-rifai, H. (1987) 'Cultural and Historical Features of Kuwait Sea Song Music', Proceedings of the Seminar for Arabian Studies 17, pp. 143-162.

Alsharekh, Alanoud, and Robert, Springborg (2012) Popular Culture and Political Identity in the Arab Gulf States (Saqi Books).

Al-Ragam, Asseel (2015) 'Critical Nostalgia: Kuwait Urban Modernity and Alison and Peter Smithson's Kuwait Urban Study and Mat-Building', The Journal of Architecture 20 (1), pp. 1-20, doi:10.1080/13602365.2014.1000679

Big, D. (2012) 'Kuwaiti Rapper YouTube'. Available from: https://www.youtube.com/watch?v=91UMjmBfTJc and https://www.youtube.com/watch?v=1SRhoiSk4Ek Accessed: 19 May 2021

Boylorn, R. M. (2008) 'As Seen on TV: An Autoethnographic Reflection on Race and Reality Television', Critical Studies in Media Communication 25 (4), pp. 413-433.

Boym, Svetlana (2001) The Future of Nostalgia (N.Y.: Basic Books). 
Boym, Svetlana (2007) 'Nostalgia and Its Discontents', Hedgehog Review 9 (2), pp. 7 18.

Carlos, Yoder (ed.) (2018) Bulletin ICTM: Yearbook for Traditional Music (Online) Available from: https://ictmusic.org/sites/default/files/documents/bulletins/136-ICTMBulletin-Jan-2018-good.pdf

Cainkar, Louise (2013) 'Global Arab World Migrations and Diasporas' The Arab Studies Journal 21 (1), pp. 126-165.

Calafell, B. M. (2013) '(I)dentities: Considering Accountability, Reflexivity, and Intersectionality in the I and the We', Liminalities: A Journal of Performance Studies 9 (2), pp. 6-13.

Cashman, Ray (2006) 'Critical Nostalgia and Material Culture in Northern Ireland.' The Journal of American Folklore 119 (472), pp. 137-160.

Clive, Holes, D. (2011) 'Language and Identity in the Arabian Gulf', Journal of Arabian Studies 1 (2), pp. 129-145, doi:10.1080/21534764.2011.628492

Elsadda, H. (2010) 'Arab Women Bloggers: The Emergence of Literary Counterpublics', Middle East Journal of Culture and Communication 3 (3), pp. 312-332.

Ghabra, H. S. (2020) 'Performative Communication: Palestinian Resistance, Hip-hop and Cyberspace Performances', Communication Review 23 (3), pp. 181-202, doi:10.1080/10714421.2020.1832415

Kahf, U. (2007) 'Arabic Hip Hop: Claims of Authenticity and Identity of a New Genre', Journal of Popular Music Studies 19, pp. 359-385, doi:10.1111/j.15331598.2007.00133.x

Killius, Rolf (2017) 'thaqāfah thrīah t'br 'nhā ālmūsīqī - ālālāt ālmūsīqīah fì dwl ālmnțqï ālğgrāfyah âl'lyā men ālhhlīğ âl' rabī [A rich culture expressed by music - musical instruments in the countries of the upper geographic region of the Arabian Gulf]'. Available

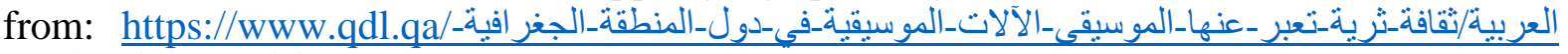
Accessed: 24 May 2021.

Kraidy, M. M. (2013) 'Contention and Circulation in the Digital Middle East: Music Video as Catalyst', Television and New Media 14 (4), pp. 271-285, Available from: https://doi.org/10.1177\%2F1527476412463450 . Accessed: 24 May 2021.

Moukhles, Kaoubi (2013) 'tōrāth ālkūwaīt [Kuwait's heritage]'. Available from: https://www.youtube.com/watch?v=12KQEZHpC8M. Accessed: 19 May 2021

Nāğy, 'āḥmd (2016) 'raḥlı̈ mwsīqī ālmhrğānāt men ḥārāt ālqāhrẗ 'lē āl'rāḍy ālfrnsyü. rașiff 22. ' $\bar{a}$ [A journey of mahraganat music from Cairo lanes to French lands. Platform22]'

Nahmah, (2017) '«ālnahmah»: thaqāfah kḥlīğīah wāḥēdah rōgemə ēkhntelāf āl' dā'. Available from: https://www.alanba.com.kw/ar/kuwait-news/744981/13-05-2017-_النهمة_ثقافة /خليجية-و احدة-ر غم-اختلاف_الأداء Accessed: 19 May 2021 
Peavey, April (2014) 'In Egypt, 'electro-chaabi' music stirs up controversy' The World PRX. Available at https://www.pri.org/stories/2014-06-24/egypt-electro-chaabi-music-stirscontroversy.

Rola, Kharsa (2015) 'ferqä̈ ālmdf' ǧīah fì bernāmğ wamād̄ā b'd m' rōwlā kharsā [A1Madfaiya music band on 'what next' show with Rola Kharsa]'. Available from: https://www.youtube.com/watch?v=93400mAN7AA, Accessed: 19 May 2021.

Sciullo, Nick J. (2019) Communicating Hip-hop: How Hip-hop Culture Shapes Popular Culture (ABC-CLIO: LLC).

Sons of Yusuf Movement: Available from: https://www.sonsofyusuf.com/ Accessed: 2605.2021.

Tan, Y., Shaw, P., Cheng, H. and Kim, K. K. (2013) 'The Construction of Masculinity: A Cross-Cultural Analysis of Men's Lifestyle Magazine Advertisements', Sex Roles 69, pp. 237-249, https://doi.org/10.1007/s11199-013-0300-5

Thomas, Burkhalter, Kay, Dickinson and Benjamin, Harbert, J. (2013) The Arab AvantGarde: Music, Politics, Modernity (Wesleyan University Press).

Urkevich, Lisa, and Liaison, Officer (2018) 'Kuwait', Bulletin of the International Council for Traditional Music 136, pp. 21, Available form http://ictmusic.org/sites/default/files/documents/bulletins/136-ICTM-Bulletin-Jan-2018good.pdf

Urkevich, Lisa (2015) Music and Traditions of the Arabian Peninsula: Saudi Arabia, Kuwait, Bahrain, and Qatar (New York and London: Routledge).

Zfat Afrah Aleursuih (2020) 'šhīlāt ḥamāsīah țarab mğānīh bedōn ḥōqūq. [Free enthusiastic rapture, copylefted]'. Available from: https://www.youtube.com/watch?v=SXdzDgmmh9E Accessed: 24 May 2021.

\section{Acknowledgements}

This research is part of a larger tandem project funded by Arab-German Young Academy of Sciences and Humanities.

\section{About the Authors}

Shahd Alshammari is Assistant Professor of English and the author of Head Above Water: Reflections on Illness (Neem Tree Press, London). She is a member of the Arab-German Young Academy of Sciences and Humanities.

Rami Chahin is Assistant Professor of Musicology and has received many awards in composition. He has been a member of the Arab-German Young Academy of Sciences and Humanities since 2018. 